\title{
Competition among mangrove oomycotes, and between oomycotes and other microbes
}

\author{
Steven Y. Newell ${ }^{1, *}$, Jack W. Fell ${ }^{2}$ \\ ${ }^{1}$ Marine Institute, University of Georgia, Sapelo Island, Georgia 31327, USA \\ ${ }^{2}$ Rosenstiel School of Marine \& Atmospheric Science, University of Miami, 4600 Rickenbacker Causeway, Miami, \\ Florida 33149-1098, USA
}

\begin{abstract}
Competition experiments were performed using precolonized leaves or leaf disks of red mangrove Rhizophora mangle with: (1) disks containing pure cultures of single species of marine true fungi or species of Halophytophthora (the principal genus of marine oomycotes); and (2) leaves bearing bacterial films. Preoccupied leaves were exposed to natural microflorae in mangrove creeks at 2 Cays in the Bahama Islands, or placed in laboratory seawater enclosures wherein pairs of halophytophthoras were given equivalent opportunity to occupy fresh leaf material. The ubiquitous coastal-marine oomycote $H$. vesicula was found to be an able competitor versus true fungi and versus other halophytophthoras. Against other halophytophthoras, this was true for both primary and secondary resource capture. The one exception among the fungi was a species (Dendryphiella salina) common in decaying drift material in high-intertidal zones. $H$. spinosa was a weak competitor with true fungi and with $H$. vesicula, though it was not displaced by $H$. vesicula, and $H$. spinosa could depress the frequency of $H$. vesicula occupation when $H$. spinosa was well established. H. bahamensis did not routinely form sporangia, preventing identification and firm conclusions regarding competitiveness, other than that it could not block $H$. vesicula, but could block $H$. spinosa from entering its occupied arenas. When bacterial films were present on leaves prior to access by halophytophthoras, the occupation frequency of halophytophthoras was sharply depressed (by about 70 to $90 \%$ with 48 h bacterial films), including for $H$. vesicula, implying that in some types or parts of mangrove systems, submerged-leaf decomposition may sustain low levels of participation by halophytophthoras.
\end{abstract}

KEY WORDS: Oomycotes - Halophytophthora Fungi Bacteria Competition - Mangrove - Rhizophora

\section{INTRODUCTION}

Eukaryotic mycelial decomposers are potentially important secondary producers in coastal zones where there is high productivity by vascular plants (Newell 1996). In saltmarshes, marshgrass shoots are the basis for high productivity by fungi (rough estimate: $325 \mathrm{~g}$ $\mathrm{m}^{-2} \mathrm{yr}^{-1}$, principally by ascomycetes) (Newell 1993, 1996, Newell et al. 1996). In mangrove ecosystems, there is evidence that oomycotes, rather than fungi, are the major mycelial decomposers of submerged leaves (Newell 1996). The oomycotes are mycelial protoctists that have swimming propagules (zoospores) resembling planktonic heterotrophic flagellates (Dick 1990,

\footnotetext{
•E-mail: newell@uga.cc.uga.edu
}

Nakagiri 1993, Fell \& Newell 1997, Kohlmeyer et al. 1997). The oomycotes were formerly termed 'zoosporic fungi', and are still alternatively referred to as 'chromistan fungi' or Peronosporomycetes (Dick 1995), although they are not evolutionarily close to the Kingdom Fungi (references in Erwin \& Ribeiro 1996, Fuller 1996, Newell 1996). We use the word 'fungi' herein only to refer to members of the Kingdom Fungi.

The most prominent marine oomycotic species is Halophytophthora vesicula (Anastasiou et Churchland) Ho et Jong, which can be found at high frequency ( $\geq 90 \%$ of small samples of decaying leaves) in mangrove ecosystems and temperate marine coastal systems where there is high input of leaf litter (e.g. Newell \& Fell 1994, 1995). H. vesicula has been found in marine ecosystems in both hemispheres at the edges of the Atlantic, Caribbean, Pacific, and Indian Oceans 
(Fell \& Master 1975, Nakagiri et al. 1996). Halophytophthoras of secondary occurrence frequency to $H$. vesicula are $H$. spinosa (Fell et Master) Ho et Jong, $H$. kandeliae Ho, Chang et Hsieh, and H. exoprolifera Ho, Nakagiri et Newell (Newell \& Fell 1995, Nakagiri et al. 1996). Rare species ( $\leq 10 \%$ frequency) include $H$. bahamensis (Fell et Master) Ho et Jong and $H$. epistomium (Fell et Master) Ho et Jong (Newell \& Fell 1995).

Halophytophthoras can be detected in fallen mangrove leaves within $2 \mathrm{~h}$ of leaf fall, and frequencies of internal mycelium approaching or equalling $100 \%$ can be found by 24 to $48 \mathrm{~h}$ after leaf submergence (Newell et al. 1987. Newell 1996). It has been speculated that this rapid occupation of fallen leaves is a means of coping with competition from microbial films that form on leaves (including protozoa and labyrinthulids that are potential predators upon halophytophthoras) (Newell \& Fell 1995). Although ergosterol contents of submerged, decaying mangrove leaves strongly suggest that fungi are not usually successful competitors with halophytophthoras for submerged mangrove-leaf substrates (Newell \& Fell 1992a), marine fungi are regularly found in submerged, decaying mangrove leaves by culturing techniques (Newell 1996), and may also have the potential for successful competition with halophytophthoras, given appropriate environmental conditions (e.g. perhaps, the intermittent drying of the upper intertidal zone; Newell \& Fell 1992a).

Study of competition among eukaryotic mycelial decomposers has been more strongly targeted to fungi (Cooke \& Whipps 1993, Robinson et al. 1993, Wardle et al. 1993) than to oomycotes, although competition experiments have been performed with species of oomycotic plant pathogens (e.g. Holmes \& Benson 1994), with true fungi and oomycotic plant pathogens or oomycotic parasites of fungi (e.g. Lederer et al. 1992, Jones \& Deacon 1995), and with oomycotic plant pathogens and potential bacterial biocontrol agents (e.g. Fukui et al. 1994). We report here our experimental testing of the competitiveness of halophytophthoras versus bacterial assemblages and marine fungi, with respect to secondary resource capture (the taking of previouslyheld territory; Cooke \& Whipps 1993). We also tested capacity for both primary and secondary resource capture among 3 species of mangrove halophytophthoras, one ubiquitous (Halophytophthora vesicula), 1 of secondary occurrence frequency $(H$. spinosa), and 1 rare (H. bahamensis).

\section{METHODS}

Sites. Experiments were performed at 2 sites in the Bahama Islands, Mangrove Cay north of Grand Bahama $\left(26^{\circ} 54.4^{\prime} \mathrm{N}, 78^{\circ} 37.4^{\prime} \mathrm{W}\right)$ and Manjack Cay, Abaco Islands $\left(26^{\circ} 49.1^{\prime} \mathrm{N}, 77^{\circ} 21.9^{\prime} \mathrm{W}\right)$ during May 1996. Temperatures and salinities at station sites in the mangrove creeks ranged from 23 to $31^{\circ} \mathrm{C}$ and 24 to $36 \%$ (Mangrove Cay) and from 26 to $32^{\circ} \mathrm{C}$ and 30 to $34 \%$ (Manjack Cay). There was rainfall from scattered storms at both stations during exposure of experimental leaves. The Manjack site was 'Station C' of Newell et al. (1987). Red mangrove trees bordering the creeks were approximately $4 \mathrm{~m}$ tall at both sites. At the Mangrove Cay site, the creek was approximately $3 \mathrm{~m}$ deep by $3 \mathrm{~m}$ wide at mean low water (MLW) at the experimental station, with walls steeply sloping away from the edge of the mangrove-proproot zone, so that deposits of naturally decaying leaves accumulated at the creek bottom, away from the proproots. At the Manjack Cay site, leaf deposits accumulated among and adjacent to the proproots; the creek was about $6 \mathrm{~m}$ wide by 0.3 to $1 \mathrm{~m}$ deep at MLW at the bag-attachment site (see below).

Three types of senescent leaves of red mangrove Rhizophora mangle L. were employed: (1) leaves sterilized, inoculated, and incubated with pure cultures of particular microbes before field exposure; (2) leaves not presterilized, and exposed to pairs of oomycotes in non-sterile seawater; (3) leaves not presterilized, but preincubated with mangrove-ecosystem microbes that could pass $1.2 \mu \mathrm{m}$ glass-fiber filters before field exposure (Table 1). We used autoclaving in our Expt 1 to ensure that our intended preoccupying microbes

Table 1 Basic summary of Expts 1 to 3 involving disked or whole yellow senescent leaves of red mangrove Rhizophora mangle that were picked from trees, treated, subsequently submerged in the mangrove ecosystem (Expts 1 and 3 ) or in seawater from offshore of the mangroves (Expt 2), and then sampled to detect outcome of competition for leaf occupation

\begin{tabular}{|lll|}
\hline Expt & Type of intended competitor & Treatment of experimental yellow leaves \\
\hline 1 & Preestablished mycelial & $\begin{array}{l}\text { Disks autoclaved, and inoculated (or not) with pure cultures } 2 \text { to } 3 \text { wk } \\
\text { before natural mangrove-ecosystem submergence } \\
\text { Disks not presterilized; juxtaposed to source of mycelium of pairs of } \\
\text { oomycotes immediately before submergence } \\
\text { Whole leaves not presterilized; exposed (or not) to natural bacterial } \\
\text { suspension prior to exposure in mangrove system. }\end{array}$ \\
\hline
\end{tabular}


would be well established when placed in the field to face competition from naturally occurring microbes. We recognize that autoclaving causes change in the leaf substrate that could affect microbial activity during field exposure, but no presterilizing method is without this fault, including the often-recommended gamma sterilization (Coleman \& Macfadyen 1966. Frankland et al. 1990). It should be noted in this connection that the same 2 oomycotic species were predominant occupants of both autoclaved and nonautoclaved disks (control leaves for Expts 1 and 3, respectively; see below); these are the same predominant species (Halophytophthora vesicula and $H$. spinosa) that have been found for new-fallen leaves of red mangrove in several previous studies, in which exposure of presterilized leaves was not performed (e.g. Newell \& Fell 1995, 1996, and references therein).

Expt 1: competition with a well-established occupant. Leaves were picked directly from trees at the senescent, yellow stage, and stored at $-20^{\circ} \mathrm{C}$. They were thawed and used to obtain 330 disks of $1.4 \mathrm{~cm}$ diameter (cork borer). The disks were autoclaved (30 min) in glass dishes ( 15 disks per $100 \times 15 \mathrm{~mm}$ dish) with $5 \mathrm{ml}$ tapwater Sets of 15 sterilized disks were placed at the growing edge of mycelium of one of 9 species of mangrove fungi or oomycotes, on a plate of dilute V-8 agar (Newell \& Fell 1994) made with 15\% seawater. Two sets of uninoculated control disks were prepared, one on V-8 agar, and one that was kept in the original glass sterilizing dish. Disks were incubated at $25^{\circ} \mathrm{C}$ in diffuse daylight (about $20 \mu \mathrm{E} \mathrm{m}^{-2} \mathrm{~s}^{-1}$ ) with a natural light/dark cycle for 2 to 3 wk.

Three of the precolonizing species were marine fungi (Kohlmeyer \& Volkmann-Kohlmeyer 1991), all isolated from decaying leaves of red mangrove: Dendryphiella salina (Sutherland) Pugh et Nicot (culture accession number SAP 30); Lulworthia sp. (SAP 56); and Zalerion varium Anastasiou (SAP 58). The first species is characteristic of intertidally decaying plant material (Kohlmeyer \& Kohlmeyer 1979, Miller \& Whitney 1981, Genilloud et al. 1994); the other 2 of submerged decaying leaves (Newell et al. 1987). The Dendryphiella species used exhibited characteristics intermediate between the descriptions of $D$. salina and $D$. arenaria Nicot (most conidia with $\leq 3$ septa, but some with as many as 6 septa), so it is listed here as $D$. salina, the taxonomically older species (based on Cercospora salina Sutherland 1916: Kohlmeyer \& Kohlmeyer 1979). All 3 species had produced propagules (conidia or ascospores) on/in the presterilized disks after 2 wk of incubation.

The remaining 6 strains of precolonizing microbes were marine oomycotes (Kohlmeyer et al. 1997) isolated from submerged decaying leaves of red mangrove. These were species of the genus Halophytophthora Ho et Jong, with 2 strains each: $H$. vesicula [SAP 40 (= ATCC 64763) and 88]; H. spinosa var. spinosa (Fell et Master) Ho et Jong (SAP 87 and 97); H. bahamensis (Fell et Master) Ho et Jong [SAP 38 (= CBS 153.96) and 113]. SAP 40 and 88 are examples of the 'delicate-vesicle' variety of $H$. vesicula (Kohlmeyer et al. 1997). The $H$. vesicula and $H$. spinosa strains produced sporangia on the presterilized disks after $2 \mathrm{wk}$ of incubation, but the $H$. bahamensis strains produced only mycelium.

Precolonized disks and uncolonized controls were exposed in mangrove creeks at Mangrove and Manjack Cay. Disks were placed in nylon-mesh bags ( $4 \mathrm{~mm}^{2}$ mesh, $12 \times 12 \mathrm{~cm}, 15$ disks from 1 treatment per bag) along with a label (a marked $2.5 \mathrm{~cm}$ watchglass), and these small bags were placed together into a larger nylon-mesh bag $(30 \times 30 \mathrm{~cm})$. Approximately 30 naturally submerged decaying leaves of red mangrove collected near the bag-tying sites were mixed into the larger nylon bag among the smaller bags (to provide a natural source of zoospores of marine oomycotes; Newell \& Fell 1992b, 1996). The bags of disks were submerged and tied to proproots of red mangroves 1 to $5 \mathrm{~cm}$ below the level of mean low water, at a location about 50 m upstream from the mouth of a creek draining the mangroves. Precolonized control disks for the Halophytophthora species were directly plated onto $\mathrm{A} / \mathrm{T}$ medium as controls, and incubated as described below for the field-exposed disks.

After $48 \mathrm{~h}$ of exposure, the bags of disks were retrieved and kept in seawater until sampled (within $3 \mathrm{~h}$ ). Disks were removed from each small bag, drained of free water, and placed on plates of A/T medium (Newell \& Fell 1996, Kohlmeyer et al. 1997), an agar preparation that is selective for oomycotes [contains amphotericin-B (2.5 $\left.\mathrm{mg}^{-1}\right)$ and thiabendazole $(10 \mathrm{mg}$ $\left.\mathrm{l}^{-1}\right)$ to inhibit true fungi, and ampicillin (250 $\mathrm{mg} \mathrm{l}^{-1}$ ). chloramphenicol (10 $\left.\mathrm{mg} \mathrm{l}^{-1}\right)$, and rifampicin $\left(10 \mathrm{mg} \mathrm{l}^{-1}\right)$ to inhibit bacteria]. Plates were incubated in darkness for $4 \mathrm{~d}$, and then under a 12:12 h light:dark cycle $150 \mu \mathrm{E}$ $\mathrm{m}^{-2} \mathrm{~s}^{-1}$ ), at $25^{\circ} \mathrm{C}$. Plates were examined under the dissecting microscope $(\times 25$ to $\times 100)$ for presence of oomycotes (with confirmations under a compound research microscope) (Kohlmeyer et al. 1997).

Expt 2: competition with equal initial status. Precolonized disks of red-mangrove leaves were used as in Expt 1 (Table 1), containing the same species and strains of Halophytophthora. For Expt 2, the precolonized disks were paired (all combinations of the strains used). Each pair of disks was placed together, and a smaller disk $(0.6 \mathrm{~cm}$ diameter $)$ was simultaneously removed from the center of both precolonized disks. Then a $0.6 \mathrm{~cm}$ disk from a yellow (senescent) red-mangrove leaf collected from trees at the Mangrove Cay site was inserted into the hole in the pair of precolonized disks. The fresh yellow leaf-disk was thus equiv- 
alently exposed to mycelial entry at its periphery from both strains of a pair of species. Three replicates of these 'filled-doughnut-hole' preparations were made for each pair of halophytophthoran strains. The filled doughnut holes' were placed into plastic flow-through enclosures $(8 \mu \mathrm{m}$ screening at each end of a cylinder, $10 \times 2 \mathrm{~cm}$; Newell \& Fell 1996) and immediately placed into a $6 \mathrm{l}$ volume of seawater (collected from about $200 \mathrm{~m}$ outside of the mangroves where no propagules of marine mycelial oomycotes would be expected; Newell \& Fell 1992b, 1996). The enclosures were incubated outdoors in the $6 \mathrm{I}$ bucket for $5 \mathrm{~d}$, out of direct sunlight (temperature range, 25 to $34^{\circ} \mathrm{C}$ ).

After incubation, enclosures were opened and the small yellow disks were removed. The small disks were drained of free water, placed on plates of $A / T$ medium, and incubated and examined as for Expt 1.

Expt 3: competition with established bacterial assemblages. Two $200 \mathrm{ml}$ water samples were collected in screw-cap bottles from just above naturally decaying red-mangrove leaves at each of the cays. Two naturally decaying red-mangrove leaves were added to each sample. These were shaken for $10 \mathrm{~s}$ by hand, and $120 \mathrm{ml}$ from each sample was pushed through a Whatman GF-C syringe filter $(1.2 \mu \mathrm{m}$ nominal pore size, $2.5 \mathrm{~cm}$ diameter) into a 21 volume of seawater from $200 \mathrm{~m}$ outside of the mangroves. To one of the two $2 \mathrm{I}$ volumes were added 17 yellow red-mangrove leaves picked from trees at the cay sites. Both 21 volumes were incubated outdoors out of direct sunlight, with stirring approximately every $8 \mathrm{~h}$. After $24 \mathrm{~h}$, the second $2 \mathrm{l}$ volume received 17 yellow leaves. After a further $24 \mathrm{~h}, 15$ leaves from each bucket were transferred to $30 \times 30 \mathrm{~cm}$ nylon-mesh bags $\left(4 \mathrm{~mm}^{2}\right.$ mesh), and tied to red-mangrove proproots as in Expt 1. Also, 15 yellow leaves that had not received exposure to $1.2 \mu \mathrm{m}$ filtrates were placed in a $30 \times 30 \mathrm{~cm}$ nylon bag and tied to proproots. Alongside the bags of yellow leaves, a bag of 50 naturally submerged decaying redmangrove leaves was tied as a natural zoospore-source (Newell \& Fell 1996). The remaining 2 leaves from each of the sets exposed to $1.2 \mu \mathrm{m}$ filtrates were used to provide controls for the potential presence of oomycotes in the filtrates. Four $0.6 \mathrm{~cm}$ diameter disks were taken from each leaf and plated on $A / T$ medium as described below.

After 26 (Mangrove Cay) or 46 (Manjack Cay) h, the bags of yellow leaves were retrieved. Leaves were drained of free water and two $0.6 \mathrm{~cm}$ diameter disks were taken from each leaf with a sterile cork-borer (Kohlmeyer et al. 1997) and plated on A/T medium, with incubation and examination as for Expt 1.

Identifications and statistics. Identifications of oomycotes were based upon references listed in Kohlmeyer et al. (1997). Voucher specimens are available from
S.Y.N. Frequencies of occurrence were compared using the $R \times C G$-test of Sokal \& Roblf (1995).

\section{RESULTS}

\section{Expt 1}

Four species of oomycotes were encountered on field-exposed control (not precolonized) disks: Halophytophthora vesicula (delicate-vesicle variety), $H$. spinosa var. spinosa, $H$. exoprolifera, and Pythium grandisporangium Fell et Master. The former 2 were most common (to $93-100 \%$ of control disks) (Table 2), and the latter 2 rare $(7 \%$ maximum). $H$. bahamensis sporangia were not found for field-exposed control disks. There were no significant $(p<0.05)$ differences between occurrence frequencies for the 2 types of field-exposed control disks (agar plated or not), nor for disks of any 2 strains of preinoculated oomycote species, so the control data and species-strain data were pooled in Table 2 .

Control disks plated directly onto A/T medium (no field exposure) for the halophytophthoras all exhibited immediate growth, and the strains of Halophytophthora vesicula and $H$. spinosa formed abundant sporangia. The 2 strains of $H$. bahamensis, however, though forming mycelium as rapidly as the other 2 species of Halophytophthora, did not form sporangia on the control plates.

Disks preoccupied by Dendryphiella salina exhibited 1 occurrence of Halophytophthora vesicula and none for $H$. spinosa (Table $2 ; \mathrm{p}<0.05$ vs control), although Pythium grandisporangium was able to co-

Table 2. Frequencies of occurrence from Expt 1 (Table 1) for Halophytophthora vesicula (Hv) and $H$. spinosa (Hs) from disks of red-mangrove leaves preinoculated with species of marine fungi (Dendryphiella salina, Lulworthia sp., Zalerion varium) or oomycotes $(H$. vesicula, $H$. spinosa, $H$. bahamensis), then exposed ( $48 \mathrm{~h})$ in 2 mangrove creeks (Mangrove Cay and Manjack Cay). Control disks were not preinoculated. Least-significant $\left(p<0.05, R \times C G\right.$-test) difference $\left(\mathrm{LSD}_{0} 05\right)$ between control and any other frequency, 17 percentage units for oomycote-preoccupied disks (total $n=60$ ), 24 percentage units for fungal-preoccupied disks $(n=45)$

\begin{tabular}{|lrrrr|} 
Preestablished & \multicolumn{3}{c}{$\begin{array}{c}\text { Mangrove Cay } \\
\text { species }\end{array}$} & \multicolumn{2}{c|}{$\begin{array}{c}\text { Manjack Cay } \\
\% H \mathrm{HV}\end{array}$} & $\% \mathrm{Hs}$ \\
\hline D. salina & 0 & 0 & 7 & 0 \\
Lulworthia sp. & 100 & 0 & 80 & 20 \\
Z. varium & 100 & 0 & 67 & 0 \\
H. vesicula & 100 & 0 & 100 & 7 \\
H. spinosa & 47 & 100 & 80 & 100 \\
H. bahamensis & 90 & 7 & 87 & 17 \\
Control & 100 & 93 & 90 & 57 \\
& & & & \\
\end{tabular}


occupy $53 \%$ of these disks at Manjack Cay ( $p<0.05$ vs control frequency of $7 \%$ ) (data not shown). Disks preoccupied by the other 2 true fungi tested (Lulworthia sp., Zalerion varium) were co-occupied by $H$. vesicula (67 to $100 \%$; but $\mathrm{p}<0.05$ vs control for Manjack), whereas $H$. spinosa exhibited 0 to $20 \%$ frequencies on fungal-preoccupied disks ( $p<0.05$ vs control) (Table 2). There was only 1 case of occurrence of $H$. bahamensis on fungal-preoccupied disks: $27 \%$ on $\mathrm{Lul}$ worthia disks at Manjack Cay.

Disks preoccupied by Halophytophthora vesicula exhibited occurrences of $H$. spinosa at a maximum of $7 \%$ ( $\mathrm{p}<0.05$ vs control). Preoccupation by $H$. spinosa allowed 47 to $80 \%$ occurrence of $H$. vesicula $(\mathrm{p}<0.05$ vs control). Disks preoccupied by $H$. bahamensis were the only ones among the oomycote-preoccupied ones for which sporangia of $H$. bahamensis were found, and even then at a maximum of only $33 \%$ (compare results for $H$. vesicula and $H$. spinosa on self-preoccupied disks in Table 2). However, disks preoccupied by $H$. bahamensis allowed only a maximum of $17 \%$ frequency for $H$. spinosa ( $\mathrm{p}<0.05$ vs control), but 87 to $90 \%$ frequency for $H$. vesicula (p > 0.05 vs control). Sporangia of $H$. vesicula occurring on mycelium from $H$. bahamensis-preoccupied disks were always visibly smaller and fewer than associated with other types of disks revealing $H$. vesicula.

\section{Expt 2}

When paired with Halophytophthora spinosa or $H$. bahamensis, $H$. vesicula always appeared on the A/Tplated disk (the 'doughnut-hole' disk), in all 24 of the possible cases. When paired with $H$ vesicula, $H$. spinosa appeared in 3 of 12 possible cases ( $p<0.05$ vs frequency of $H$. vesicula). When paired with $H$. bahamensis, $H$. spinosa appeared in 7 of 12 cases. $H$. bahamensis appeared only once (as identifiable sporangia), when paired with $H$. spinosa. In pairings of $H$. spinosa and $H$. bahamensis, $H$. vesicula appeared in 7 of 12 cases; since it was not present in the original disks (the 'doughnut' disks) placed into these $8 \mu \mathrm{m}$ screened tubes, it must have gained access to the 'doughnuthole' disks in these pairings as zoospores that swam through the screening twice, out of a tube containing $H$. vesicula and into one originally not containing $H$. vesicula.

\section{Expt 3}

The only oomycotes encountered in this experiment were Halophytophthora vesicula and $H$. spinosa. Control disks exposed to the $1.2 \mu \mathrm{m}$ filtrates, but not ex-

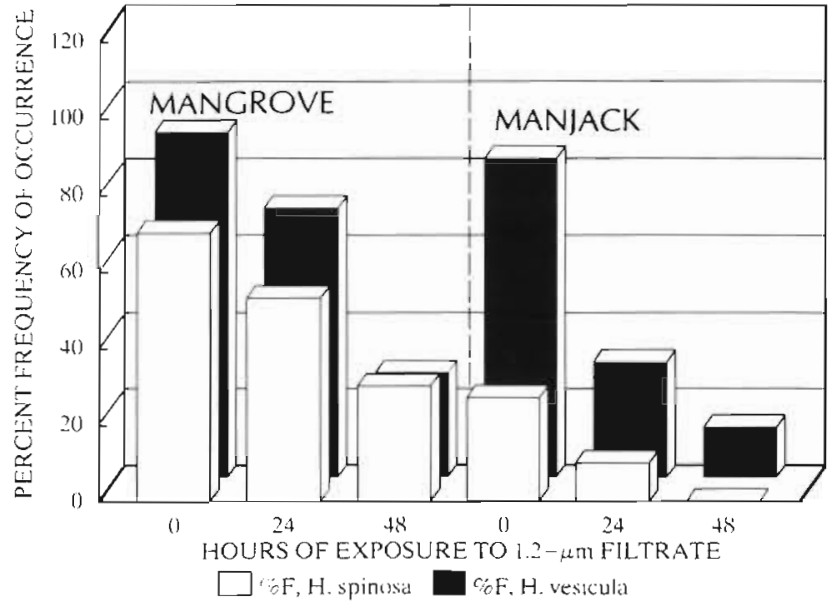

Fig. 1. Frequencies of occurrence for Halophytophthora vesicula and $H$. spinosa from disks of red-mangrove leaves exposed for 0 to $48 \mathrm{~h}$ to $1.2 \mu \mathrm{m}$ filtrate of a bacterial suspension from decomposing red-mangrove leaves, prior to exposure for 1 to $2 \mathrm{~d}$ in mangrove creeks. First 3 sets of bars, left to right, are for Mangrove Cay; second 3 sets are for Manjack Cay. $\mathrm{LSD}_{005}$ (see Table 2 heading) between any 2 frequencies, 17 percentage units (total $n=60$ )

posed in the mangrove creeks, exhibited no occurrences of halophytophthoras $(n=32)$. Exposure of yellow leaves of red mangrove to $1.2 \mu \mathrm{m}$ filtrates of bacterial suspensions from decomposing leaves caused significant ( $p<0.05$ ) decreases (by 17 to 53 percentage units) in frequency of occurrence for both halophytophthoras after $24 \mathrm{~h}$ of bacterial access to leaves (Fig. 1). After $48 \mathrm{~h}$, frequencies of halophytophthoras were reduced by $\geq \times 2$ at Mangrove Cay, and to $\leq 13 \%$ at Manjack Cay (Fig. 1). Frequencies of disks negative for halophytophthoras rose with time of exposure to $1.2 \mu \mathrm{m}$ filtrates, from $3-17 \%$ with no pre-exposure to bacterial suspensions, to $67-87 \%$ with 48 h exposure to bacterial suspensions.

\section{DISCUSSION}

Competition among species of mycelial decomposers is known to be a determinant of the degree to which individuals are successful in capturing substrate (Cooke \& Whipps 1993, Robinson et al. 1993 Rayner 1994, 1996), although use of manipulation experiments in the field (e.g. Wardle et al. 1993), for comparison to laboratory pairings, has not been common (Shearer 1995). By manipulating the content of halophytophthoras within red-mangrove leaves, in samples exposed in the field and the laboratory, we found that one likely reason for the predominance of Halophytophthora vesicula in submerged, decaying leaves of Rhizophora (Nakagiri et al. 1989, Newell 
1996) and other maritime leaves (Newell 1992) is that this species is an aggressive competitor. Not only was $H$. vesicula able to co-occupy substrates that contained well-established fungi (except for Dendryphiella salina substrates), $H$. vesicula blocked $H$. spinosa almost entirely when $H$. vesicula was the first occupier of leaves (Table 2). When $H$. vesicula and $H$. spinosa had equivalent opportunity to move together into new substrate (Expt 2), there was co-occupation by $H$. spinosa in only $25 \%$ of the possible cases. $H$. vesicula co-occupied disks even when it had to swim to them as zoospores from outside of experimental enclosures in Expt 2, behavior not evidenced by $H$. spinosa.

It may be that Halophytophthora spinosa must precede $H$. vesicula in finding and occupying substrates in order to successfully compete with $H$. vesicula, as evidenced by the partial suppression of $H$. vesicula that occurred when $H$. spinosa was well established (Table 2). This would be consistent with the finding that $H$. spinosa var spinosa is the predominant halophytophthora in submerged decaying Rhizophora leaves only when there are not large submerged leaflitter deposits near new-fallen leaves (Newell \& Fell 1995). This may imply that the zoospores (or zoospore cysts) of $H$. spinosa are better long-term survivors of the planktonic period of their existence (see Verity \& Smetacek 1996).

Halophytophthora bahamensis also did not prevent co-occupation by $H$. vesicula, even when it was well established, although it (or invading $H$. vesicula) did sharply depress occupation by $H$. spinosa (Table 2). Whether $H$. bahamensis could co-occupy disks containing other oomycotes or fungi, well established or not, cannot be determined from the present results, because the 2 strains of $H$. bahamensis used did not form sporangia in control preparations that contained no competitors. Therefore, it could not be determined whether $H$. bahamensis was present in disks not preinoculated with this species. We cannot conclude whether or not $H$. bahamensis is a weak competitor, or whether it is truly rare, until we learn more about its requirements for sporangium genesis, or until we attempt to detect its presence using non-cultural methods (Bermingham et al. 1997, Fell \& Newell 1997).

The one species of fungus that provided effective obstruction of Halophytophthora vesicula was Dendryphiella salina (Table 2), which is the one fungal species among the 3 tested that is not common as an occupant of submerged decaying leaves of Rhizophora (Newell et al. 1987). D. salina is a cosmopolitan species of decaying matter (perhaps especially drift macroalgae) of marine intertidal and supratidal zones (Kohlmeyer \& Kohlmeyer 1979, Pugh \& Beeftink 1980,
Schaumann \& Weide 1995). There is preliminary evidence that leaves decaying in the high-intertidal zone, where regular drying takes place, have fungi rather than oomycotes as their principal decomposers (Newell \& Fell 1992a). High competitiveness of intertidal fungi may act in concert with water-availability stress in shifting the competitive balance away from oomycotes in high-intertidal zones. Note that $D$. salina produces secondary metabolites (trinoreremophilanes) with potential antimicrobial activity (Guerriero et al. 1989).

The periods during which the yellow leaves of Expt 3 were exposed to $1.2 \mu \mathrm{m}$ filtrates of bacterial suspensions ( 24 and $48 \mathrm{~h}$ ) were less than has been found to lead to maximum bacterial coverage of newly submerged leaves of red mangrove (Benner et al. 1988 , Blum et al. 1988). Benner et al. (1988) found a plateau $\left(3 \times 10^{8}\right.$ cells $\mathrm{cm}^{-2}$ leaf surface) at $5 \mathrm{~d}$, and Blum et al. (1988) found continuously increasing bacterial mass (per $\mathrm{g}$ remaining leaf) through $40 \mathrm{~d}$ of decay. Even so, when bacterial films (including small protozoa from the filtrates (Newell et al. 1986) and other protozoa from the unfiltered seawater in the suspension) were given $24 \mathrm{~h}$ to form, halophytophthoran accupancy of leaves was depressed by about 20 to $50 \%$ and after $48 \mathrm{~h}$ of bacterial activity, about 70 to $90 \%$ of leaves were unoccupiable by halophytophthoras (Fig. 1). Yellow red-mangrove leaves are reported to float for 1 to $2 \mathrm{~d}$ after falling into seawater (Findlay et al. 1986), and in our present enclosures, the fraction floating after $24 \mathrm{~h}$ was $47 \%$, and after $48 \mathrm{~h}, 12 \%$. Newell \& Fell (1992b) found that leaves placed at or near the surface of mangrove water columns could exhibit rates of occupation by halophytophthoras $\leq 30 \%$ of the rates found directly adjacent to naturally decomposing leaves on the sediment surface. Thus, in sites such as the tidal creek of Mangrove Cay, where new-fallen leaves are commonly swept out of the mangrove stand, and where the natural submerged deposits of leaves are meters below the proproots (see 'Methods'), it may be that some fraction of fallen leaves is enwrapped by bacterial films that are effective blockades to entry of leaves by halophytophthoras, so that not all submerged decaying leaves experience halophytophthoran decompositional activity. If so, halophytophthoran capacity for rapid attachment and entry into new-fallen leaves (Newell et al. 1987) may have evolved as a mechanism for successful competition with bacterial assemblages.

Acknowledgements. This research was financially supported by USNSF grants OCE-950410S and 9521588 . We thank B. Newell, A. Statzell-Tallman, and the crew of RV 'Calanus' cruise 9603 (R. Kniffin, master, and R. Lapsley, engineer) for technical assistance. This is contribution 796 of the University of Georgia Marine Institute. 


\section{LITERATURE CITED}

Benner R, Hodson RE, Kirchman D (1988) Bacterial abundance and production on mangroves during initial stages of leaching and biodegradation. Arch Hydrobiol Beih Ergebn Limnol 31:19-26

Bermingham S, Maltby L, Dewey FM (1997) Immunoassays for the study of natural assemblages of aquatic hyphomycetes. Microb Ecol (in press)

Blum LK, Mills AL, Zieman JC, Zieman RT (1988) Abundance of bacteria and fungi in seagrass and mangrove detritus Mar Ecol Prog Ser 42:73-78

Coleman DC, Macfadyen A (1966) The recolonization of gamma-irradiated soil by small arthropods. Oikos 17 $62-70$

Cooke RC, Whipps JM (1993) Ecophysiology of fungi. Blackwell Scientific, Oxford

Dick MW (1990) Phylum Oomycota. In: Margulis L, Corliss JO, Melkonian M, Chapman DJ (eds) Handbook of Protoctista. Jones \& Bartlett, Boston, p 661-685

Dick MW (1995) Sexual reproduction in the Peronosporomycetes (chromistan fungi). Can J Bot 73(Suppl 1) S712-S724

Erwin DC, Ribeiro OK (1996) Phytophthora diseases worldwide. APS Press, St Paul, MN

Fell JW, Master IM (1975) Phycomycetes (Phytophthora spp nov. and Pythium sp. nov.) associated with degrading mangrove (Rhizophora mangle) leaves. Can J Bot 53 $2908-2922$

Fell JW, Newell SY (1997) Biochemical and molecular methods for the study of marine fungi. ln: Cooksey KE (ed) Molecular approaches to the study of the oceans. Chapman \& Hall, London (in press)

Findlay RH, Fell JW, Coleman NK, Vestal JR (1986) Biochemical indicators of the role of fungi and thraustochytrids in mangrove detrital systems. In: Moss ST (ed) Biology of marine fungi. Cambridge University Press, Cambridge, p $91-103$

Frankland JC, Dighton J, Boddy L (1990) Methods for studying fungi in soil and litter. In: Grigorova R, Norris JR (eds) Methods in microbiology, Vol 22. Academic Press, London, p 343-404

Fukui R, Schroth MN, Hendson M, Hancock JG (1994) Interaction between strains of pseudomonads in sugar beet spermospheres and their relationship to pericarp colonization by Pythium ultimum in soil. Phytopathology 84 $1322-1330$

Fuller MS (1996) The flagellated fungal spore. In: Sutton BC (ed) A century of mycology. Cambridge University Press, Cambridge, p 161-192

Genilloud O, Pelaez F, Gonzalez I, Diez MT (1994) Diversity of actinomycetes and fungi on seaweeds from the Iberian coasts. Microbiologia (Madrid) 10:413-422

Guerriero A, D'Ambrosio M, Cuomo V, Vanzanella F, Pietra F (1989) Novel trinoreremophilanes dendryphiellin B, C and $D$, eremophilanes dendryphiellin $E, F$ and $G$, and branched C-9-carboxylic acids dendryphiellic acid A and B from the marine deuteromycete Dendryphiella salina (Sutherland) Pugh et Nicot. Helvetica Chim Acta 72: $438-446$

Holmes KA, Benson DM (1994) Evaluation of Phytophthora parasitica var. nicotianae for biocontrol of Phytophthora parasitica on Cantharanthus roseus. Plant Dis 78:193-199

Jones EE, Deacon JW (1995) Comparative physiology and behaviour of the mycoparasites Pythium acanthophoron $P$. oligandrum and P. mycoparasiticum. Biocontrol Sci Technol 5:27-39
Kohlmeyer J, Kohlmeyer E (1979) Marine mycology. The higher fungi. Academic Press, New York

Kohlmeyer J, Volkmann-Kohlmeyer B (1991) Illustrated key to the fllamentous higher marine fungi. Bot Mar 34:1-61

Kohlmeyer J, Volkmann-Kohlmeyer B, Newell SY (1997) Marine and estuarine mycelial Eumycota and Oomycota. In: Mueller G, Bills G. Burdsall H, Rossman A (eds) Measuring and monitoring blological diversity. Standard methods for fungl. Smithsonlan Institution Press, Washington, DC (in press)

Lederer W, Lorenz KH, Seemüller E (1992) Studies on antagonistic effects of Trichoderma isolates against Phytophthora cactorum. J Phytopathol 136:154-164

Miller JD, Whitney NJ (1981) Fungi from the Bay of Fundy. II. Observations on fungi from living and cast seaweed. Bot Mar 24:405-411

Nakagiri A (1993) Growth and reproduction of Halophytophthora species. Trans Mycol Soc Jpn 34:87-99

Nakagiri A, Newell SY, Ito T, Tan TK (1996) Biodiversity and ecology of the oomycetous fungus Halophytophthora. In: Turner IM, Diong CH, Lim SSL, Ng PKL (eds) Biodiversity and the dynamics of ecosystems (DIWPA Series Vol 1). DIWPA, Singapore (in press)

Nakagiri A, Tokumasu S, Araki H, Koreeda S, Tubaki K (1989) Succession of fungi in decomposing mangrove leaves in Japan. Proc Int Symp Microb Ecol 5:297-301

Newell SY (1992) Autumn distribution of marine Pythiaceae across a mangrove-saltmarsh boundary. Can J Bot 70 : $1912-1916$

Newell SY (1993) Decomposition of shoots of a salt-marsh grass. Methodology and dynamics of microbial assemblages. Adv Microb Ecol 13:301-326

Newell SY (1996) Established and potential impacts of eukaryotic mycelial decomposers in marine/terrestrial ecotones. J Exp Mar Biol Ecol 200 (in press)

Newell SY, Arsuffi TL, Palm LA (1996) Misting and nitrogen fertilization of shoots of a saltmarsh grass: effects upon fungal decay of leaf blades. Oecologia (in press)

Newell SY, Fallon RD, Tabor PS (1986) Direct microscopy of natural assemblages. In: Leadbetter ER, Poindexter JS (eds) Bacteria in nature, Vol II, Methods for bacterial ecology. Plenum Publishing, New York, p 1-48

Newell SY, Fell JW (1992a) Ergosterol content of living and submerged, decaying leaves and twigs of red mangrove Can J Microbiol 38:979-982

Newell SY, Fell JW (1992b) Distribution and experimenta! responses to substrate of marine oomycetes (Halophytophthora spp.) in mangrove ecosystems. Mycol Res 96 . 851-856

Newell SY, Fell JW (1994) Parallel testing of media for measuring frequencies of occurrence for Halophytophthora spp. (Oomycota) from decomposing mangrove leaves. Can J Microbiol 40:250-256

Newell SY, Fell JW (1995) Do halophytophthoras (marine Pythiaceae) rapidly occupy fallen leaves by intraleaf mycelial growth? Can J Bot 73:761-765

Newell SY, Fell JW (1996) Cues for zoospore release by marine oomycotes in naturally decaying submerged leaves. Mycologia 88:934-938

Newell SY, Miller JD, Fell JW (1987) Rapid and pervasive occupation of fallen mangrove leaves by a marine zoosporic fungus. Appl Environ Microbiol 53:2464-2469

Pugh GJF, Beeftink WG (1980) Fungi in coastal and inland salt marshes. Bot Mar 23:651-656

Rayner ADM (1994) Pattern-generating processes in fungal communities. In: Ritz K, Dighton J, Giller KE (eds) Beyond the biomass. John Wiley, Chichester, p 247-258 
Rayner ADM (1996) Interconnectedness and individualism in fungal mycelia. In: Sutton B (ed) A century of mycology. Cambridge University Press, Cambridge, p $193-232$

Robinson CH, Dighton J, Frankland JC (1993) Resource capture by interacting fungal colonizers of straw. Mycol Res 97:547-5.58

Schaumann K, Weide G (1995) Efficiency of uronic acid uptake in marine alginate-degrading fungi. Helgol Meeresunters 49:1--4

Responsible Subject Editor: J. Dolan, Villefranche-sur-Mer, France
Shearer CA (1995) Fungal competition. Can J Bot 73(Suppl 1): S1259-S1264

Sokal RR, RohIf FJ (1995) Biometry, 3rd edn. WH Freeman \& Co, New York

Verity PG, Smetacek V (1996) Organism life cycles, predation, and the structure of marine pelagic ecosystems. Mar Ecol Prog Ser 130:277-293

Wardle DA, Parkinson D, Waller JE (1993) Interspecific competitive interactions between pairs of fungal species in natural substrates. Oecologia 94:165-172

Manuscript first received: August 23, 1996 Revised version accepted: October 29, 1996 